\title{
An Overview on the Conversion of Forest Biomass into Bioenergy
}

\author{
Qing Yu ${ }^{1,2}$, Yacheng Wang ${ }^{1}$, Quyet Van Le ${ }^{3}$, Han Yang ${ }^{1}$, Homa Hosseinzadeh-Bandbafha ${ }^{4}$, \\ Yafeng Yang ${ }^{1}$, Christian Sonne ${ }^{1,5}$, Meisam Tabatabaei ${ }^{1,4,6,7}$, Su Shiung Lam $^{1,6}$ and \\ Wanxi Peng ${ }^{1 *}$

\begin{abstract}
${ }^{1}$ Henan Province International Collaboration Lab of Forest Resources Utilization, School of Forestry, Henan Agricultural University, Zhengzhou, China, ${ }^{2}$ School of Psychology, Northeast Normal University, Changchun, China, ${ }^{3}$ Institute of Research and Development, Duy Tan University, Da Nang, Vietnam, ${ }^{4}$ Biofuel Research Team (BRTeam), Terengganu, Malaysia, ${ }^{5}$ Arctic Research Centre (ARC), Department of Bioscience, Aarhus University, Roskilde, Denmark, ${ }^{6}$ Higher Institution Centre of Excellence (HICOE), Institute of Tropical Aquaculture and Fisheries (AKUATROP), Universiti Malaysia Terengganu, Terengganu, Malaysia, ${ }^{7}$ Microbial Biotechnology Department, Agricultural Biotechnology Research Institute of Iran (ABRII), Agricultural
\end{abstract} \\ Research, Education, and Extension Organization (AREEO), Karaj, Iran
}

Biomass plays a crucial role in mitigating the concerns associated with increasing fossil fuel combustion. Among various types of biomass, forest biomass has attracted considerable attention given its abundance and variations. In this work, an overview is presented on different pathways available to convert forest biomass into bioenergy. Direct use of forest biomass could reduce carbon dioxide emissions associated with conventional energy

OPEN ACCESS

Edited by: Ao Xia,

Chongqing University, China

Reviewed by: Cheng Tung Chong, Shanghai Jiao Tong University, China Richa Arora,

Punjab Agricultural University, India

${ }^{*}$ Correspondence: Wanxi Peng pengwanxi@163.com

Specialty section: This article was submitted to Bioenergy and Biofuels, a section of the journal Frontiers in Energy Research

Received: 24 March 2021 Accepted: 21 June 2021 Published: 02 July 2021

Citation:

Yu $Q$, Wang $Y$, Van $L e ~ Q$, Yang $H$, Hosseinzadeh-Bandbafha $H$, Yang $Y$, Sonne C, Tabatabaei M, Lam SS and

Peng W (2021) An Overview on the

Conversion of Forest Biomass into Bioenergy.

Front. Energy Res. 9:684234. doi: 10.3389/fenrg.2021.684234 production systems. However, there are certain drawbacks to the direct use of forest biomass, such as low energy conversion rate and soot emissions and residues. Also, lack of continuous access to biomass is a severe concern in the long-term sustainability of direct electricity generation by forest biomass. To solve this problem, co-combustion with coal, as well as pelletizing of biomass, are recommended. The co-combustion of forest biomass and coal could reduce carbon monoxide, nitrogen oxides, and sulfide emissions of the process. Forest biomass can also be converted into various liquid and gaseous biofuels through biochemical and thermochemical processes, which are reviewed and discussed herein. Despite the favorable features of forest biomass conversion processes to bioenergy, their long-term sustainability should be more extensively scrutinized by future studies using advanced sustainability assessment tools such as life cycle assessment, exergy, etc.

Keywords: forestry, biomass, biodiesel, biogas, energy

\section{INTRODUCTION}

Greenhouse gases (GHGs) emissions and other harmful gases are among the primary global concern, mainly caused by the increasing use of fossil energy carriers (Jun-jun and Da-rui, 2012). GHGs have been thought of as a critical factor in global warming that plays a crucial role in climate change (Panahi et al., 2020b). Extensive research has shown that using other carbon sources like biomass could reduce these concerns (Hosseinzadeh-Bandbafha et al., 2018). In the literature available on the application of biomass to generate energy, the relative importance of forest biomass is debated (Vassilev et al., 2010; Gustavsson et al., 2015). Generally, the forest biomass is classified into fuelwood and industrial roundwood (Raunikar et al., 2010). Fuelwood is harvested from forestlands and directly combusted for useable heat or converted into bioenergy and biofuel and used to generate 


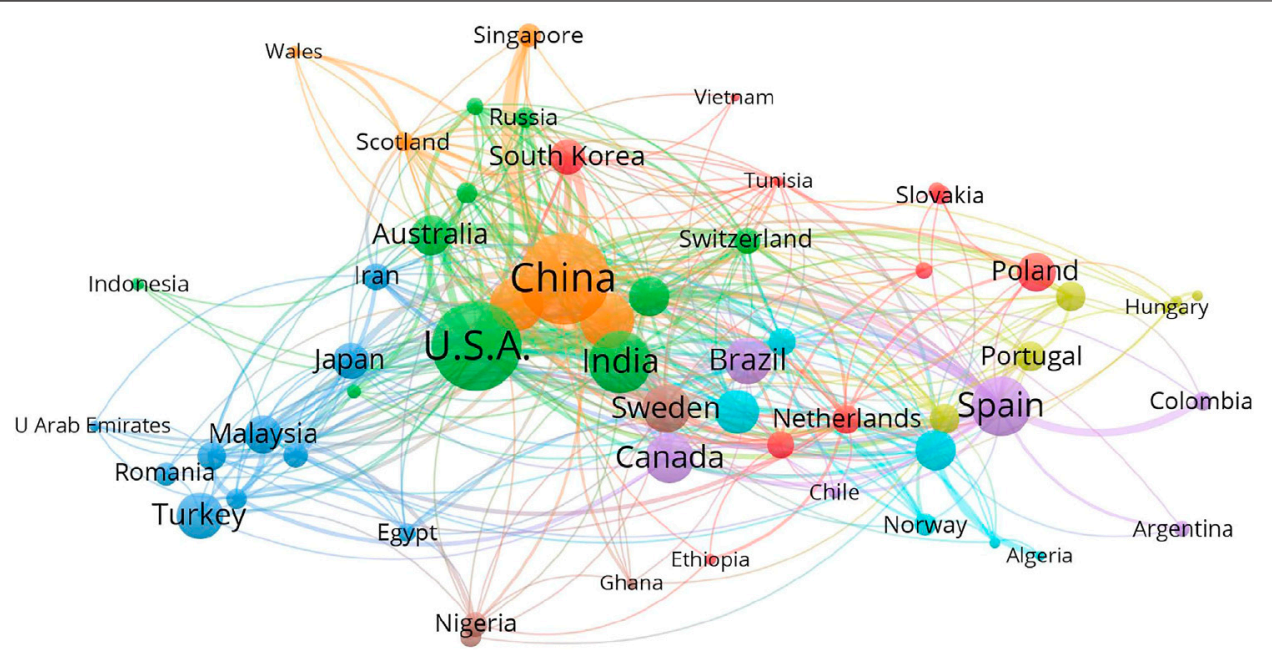

FIGURE 1 | Distribution of research activities on forest biomass to replace fossil-based energy carriers globally and the research interrelations between different countries.

TABLE 1 | Statistics by the EU on energy generation from different types of forest biomass in 2010 and estimated values in 2030.

\begin{tabular}{|c|c|c|c|}
\hline \multirow[t]{2}{*}{ Biomass species } & \multicolumn{2}{|c|}{ Biomass potential $\left(\mathbf{T J} \times 10^{4}\right)$} & \multirow[t]{2}{*}{ References } \\
\hline & 2010 & 2030 & \\
\hline Forest residues & 180 & $163-301$ & Moiseyev et al. (2014) \\
\hline Wood processing & 419 & 427 & Searle and Malins (2016) \\
\hline Forest crops & $180-193$ & $427-615$ & Böttcher and Graichen (2015) \\
\hline Total & $779-792$ & $1,017-1,343$ & \\
\hline
\end{tabular}

heat and power. More specifically, due to the high content of macromolecular sugars such as cellulose and organic matter, fuelwood is a promising feedstock for thermochemical conversion, biological conversion, liquefaction, and gasification (Perez-Garcia et al., 2005; Tan et al., 2015). Forest biomass can be used in co-combustion with fossil fuels or alone in boilers and other equipment of power generation (Scarlat et al., 2011; Calvo et al., 2013). Accordingly, when countries set their macro strategies related to energy development, efficient utilization of forest biomass resources to solve environmental crises is strongly considered (Figure 1). For example, among the available energy sources in China, $54.2 \%$ of forest biomass is used to generate power and fuel (Liao et al., 2004).

It is reported that the energy generated by forest biomass can support $15.4 \%$ of the total human energy consumption (Welfle et al., 2014). During the period 2004-2015, the whole power generation from forest biomass stood at around one million $\mathrm{kW} /$ $\mathrm{yr}$, contributing to the elimination of forest residues and achieving ecological-zero carbon dioxide $\left(\mathrm{CO}_{2}\right)$ emissions (Ince et al., 2011; Nunes et al., 2018). For instance, forest biomass application as a replacement for fossil energy in Australia reduces atmospheric $\mathrm{CO}_{2}$ emissions by 25 million tons annually (Zomer et al., 2008; Pour et al., 2018). Furthermore, the European Union (EU) statistics show that there is an increasing trend for total energy that forest waste can provide for human consumption from 2010 to 2030 (Table 1) (Urban et al., 2010).

In light of the significance of forest biomass in the global energy market in the future, the present work aims to briefly report on various methods of forest biomass conversion into bioenergy and biofuels.

\section{DIRECT UTILIZATION OF FOREST BIOMASS}

\section{Direct Combustion of Wood for Energy Production}

A significant advantage of forest biomass is that it could be directly combusted. Direct combustion is a thermochemical process during which biomass burns in the open air, and the photosynthetically stored chemical energy of the biomass is converted into heat (Lam et al., 2019). Although direct combustion of forest biomass leads to the emissions of $\mathrm{CO}_{2}$, particulates $\left(\mathrm{PM}_{2.5}\right)$, sulfur dioxide $\left(\mathrm{SO}_{2}\right)$, and other harmful substances, their amounts are still less than those caused by the combustion of fossil fuels (Karaj et al., 2010; Kacprzak et al., 2016). For example, previous research has established that the direct combustion of forest biomass generates $20 \%$ less $\mathrm{CO}_{2}$ emissions than fossil fuels (Froese et al., 2010). However, there 
TABLE 2 | $\mathrm{CO}_{2}$ emission reduction potentials of biomass-based power plants compared to their fossil fuel-based counterparts.

\begin{tabular}{|c|c|c|c|c|c|}
\hline Types of biomass & Country/Region & $\begin{array}{l}\text { Types of } \\
\text { power plants }\end{array}$ & $\begin{array}{l}\text { Capacity of } \\
\text { power plant }\end{array}$ & $\begin{array}{l}\mathrm{CO}_{2} \text { emission } \\
\text { reduction }(\mathrm{t} / \mathrm{yr})\end{array}$ & References \\
\hline $\begin{array}{l}\text { Forest waste (wood chips, wood pellets, and } \\
\text { black pellets) }\end{array}$ & Japan, Tohoku region & Thermal power plant & $500 \mathrm{MW}$ & $198,000-252,000$ & $\begin{array}{l}\text { (Furubayashi and Nakata, } \\
\text { 2018) }\end{array}$ \\
\hline Forest waste & $\begin{array}{l}\text { Portugal, Harbor of } \\
\text { Sines }\end{array}$ & Thermal power plant & $314 \mathrm{MW}$ & $1,000,000$ & (Nunes et al., 2014) \\
\hline Palm tree waste & $\begin{array}{l}\text { Iran, Bushehr } \\
\text { Province }\end{array}$ & $\begin{array}{l}\text { Rankine cycle steam } \\
\text { power plant }\end{array}$ & $8 \mathrm{MW}$ & 40,500 & (Mallaki and Fatehi, 2014) \\
\hline Forest waste (woody biomass) & Japan & Thermal power plant & $5.7 \mathrm{MW}$ & 30,934 & (Nakano et al., 2015) \\
\hline Forest waste (wood chips) & United States & Thermal power plant & $70 \mathrm{MW}$ & 552,032 & (Campbell and Mika, 2009) \\
\hline
\end{tabular}

are certain drawbacks associated with the use of forest biomass. One of these is the low energy conversion rate; moreover, direct combustion leads to soot and residues (Hong-ru and Yi-hu, 2007).

Direct combustion of biomass for power generation has continued since the 1990s (Yin et al., 2008). Biomass-fired combined heat and power (CHP) plants include a vibrating grate boiler, condensing steam turbine, and electric generator (Chen et al., 2021). The vibrating grate boiler is mechanized combustion equipment with a simple structure and small capacity. Its grate surface vibrates under the action of alternating inertial force and prompts biomass to leap forward on it to achieve mechanized combustion. Burning forest biomass produces heat within the boiler that converts water into steam (steam Rankine cycle). After water evaporation in the boiler, steam enters the turbine to expand and perform work, afterward pressure is reduced, and steam is condensed and converted to water (Dote et al., 2001). It should be noted that the steam Rankine cycle is one of the most critical thermodynamic cycles for electricity generation (Dincer and Bicer, 2020).

The conversion rate of forest biomass into electricity by Rankine cycle is reported at about 39-44\%; therefore, the combustion of each ton of forest biomass generates about $4.4 \mathrm{kWh}$ of electric energy (Van den Broek et al., 1996; Dote et al., 2001). One obvious advantage of using this electric energy is reducing fossil-based $\mathrm{CO}_{2}$ emissions caused by the power generation industry. Table 2 tabulates the $\mathrm{CO}_{2}$ emission reductions of forest biomass-based power plants compared to their fossil-based counterparts.

A significant problem with the direct combustion of forest biomass for energy production is that these waste resources are generally far from industrial and residential areas. Moreover, the forests are vast, and biomass collation is a complex problem; thus, lack of permanent access to biomass is a severe concern in the sustainability of direct electricity generation using forest biomass. Nevertheless, it is recommended that forest biomass-based industries be located within a $120 \mathrm{~km}$ radius of forests to solve this concern. Still, they need a lot of financial investment and storage capacity (Hoffmann et al., 2012).

\section{Co-combustion of Forest Biomass and Coal}

Co-combustion is a feasible and straightforward option for solving the concerns associated with the direct combustion of forest biomass, such as permanent access to biomass, the area required for storage, and economic problems related to transportation and distribution (Liang et al., 2017). The main advantage of the mixed combustion of biomass and coal vs. coal combustion is that it could reduce carbon monoxide (CO), nitrogen oxides (NOx), and sulfide emissions while ensuring production efficiency (Perea-Moreno et al., 2017). Technically, the co-combustion of forest biomass and coal uses pulverized coal boiler and fluidized bed boiler as the reactor. In the fluidized bed boiler, when forest biomass is added, the generation of nitric oxide (NO) is reduced, and the combustion process is more efficient (Kabir and Kumar, 2012). Also, compared to coal, the volatile content of biomass is higher that is a favorable parameter for rapid ignition. It has been found that 87 tons of $\mathrm{CO}_{2}$ emission could be reduced by replacing 1 ton of coal with forest biomass during co-combustion (Royo et al., 2012). It is estimated that in 2030 and beyond, biomass utilization will increase by 450,000 t/ yr, and relevant $\mathrm{CO}_{2}$ emission reduction will reach 395,000 t/yr (Kazagic et al., 2016). Furthermore, alkaline ash caused by biomass combustion can block $\mathrm{SO}_{2}$ emissions from coal and reduce global acidification (Demirba, 2005; Tsalidis et al., 2014).

Due to reducing harmful gases and increased power generation reliability, co-combustion is considered a cheap option to utilize existing biomass resources in power generation (McIlveen-Wright et al., 2011). Given this fact, thermal power plants can use biomass as clean and costeffective combustion supporting agent to mix with coal (Dai et al., 2008). However, forest biomass suffers from several significant drawbacks despite these desirable features, e.g., poor energy density, high particle emissions, unstable combustion performance, and difficulties in storage and transportation (Kang et al., 2018). Hence, future research should aim at providing solutions to mitigate these obstacles.

\section{FOREST BIOMASS PELLETS}

Several techniques have been developed to facilitate the transportation and improve the conversion rate of forest biomass, like mechanical processing of biomass into granular substance (pellet). Pelleting of forest biomass improves its density and reduces water content (Valdés et al., 2018). Density and moisture are two critical properties of biomass affecting 
combustion efficiency. Hence, direct combustion or cocombustion of pelleted forest biomass with coal could increase combustion efficiency. For instance, it has been reported that the efficiency of pellet-fired boilers ranged between 85 and $90 \%$ compared with wood-fired boilers varying from 75 to $85 \%$ (Sandro et al., 2019).

Forest biomass can also be mixed with other biomass to enhance the overall properties of the mixture for pellet production (de Souza et al., 2020). For instance, the water content of biomass pellets could affect their durability, a property that could be adjusted by mixing different types of forest biomass. More specifically, when the moisture content of forest biomass is reduced to $1-5 \%$, the average durability reaches $95 \%$, which is convenient for the storage and transportation of the product (Pradhan et al., 2018).

In the manufacturing process of forest biomass pellets, the biomass needs to be dehydrated in advance (Civitarese et al., 2018). A rotary dryer could be used to remove the moisture in poplar wood chips, with a moisture removal rate of about $17 \%$. In comparison, the moisture removal rate for Robinia pseudoacacia sawdust stands at a higher rate of $31 \%$. These differences are ascribed to the differences in the density of various types of forest biomass (Prokkola et al., 2014; Del Giudice et al., 2019). Notably, if the rotary dryer cannot remove the moisture effectively, the pneumatic dryer would be a good choice, also increasing the drying rate by $22 \%$ (Frodeson et al., 2013).

From an environmental point of view, it is reported that if biomass pellets are used instead of coal for power generation, $\mathrm{CO}_{2}$ emissions will be reduced by $205 \mathrm{Mt}$ annually (Purohit and Chaturvedi, 2018). Sikkema et al. (2011) reported that through the consumption of 8.2 million tons of wood pellets, 12.6 million tons of $\mathrm{CO}_{2}$ emissions were avoided in all EU countries in 2008.

Compared with sawdust, coal, and other traditional fuels, mixing forest biomass pellets with coal causes less harm to the environment. For example, co-combustion of forest biomass pellets and coal reportedly led to a $50 \%$ reduction in $\mathrm{CO}_{2}$ emission, and the ash formed in the combustion process only accounted for about 1\%, 15-20 times less than coal combustion (Palšauskas and Petkevičius, 2013; Morrison et al., 2018). Ehrig and Behrendt (2013) also showed that co-firing wood pellets with coal resulted in lower $\mathrm{CO}_{2}$ than other renewables. It is also claimed that adding eggshells in the combustion of forest biomass pellets could also absorb $\mathrm{CO}_{2}$ through the calcium carbonate present in eggshells, further reducing GHG emissions (Yuan et al., 2019). Molina-Moreno et al. (2016) also reported that $\mathrm{CO}$ and $\mathrm{NO}_{\mathrm{x}}$ emissions levels caused by pellets combustion were very satisfactory. Tamura et al. (2014) claimed that co-firing wood pellets with coal when wood pellets were burnt in lower row burners could prevent $\mathrm{CO}$ emissions.

Despite these promising results, power plants relying on forest biomass pellets also face several problems such as high energy consumption, labor-intensive process, higher prices than other solid biofuels, need for higher storage space in comparison with oil, need for ash removal, and susceptibility of pellets to moisture exposure (Abdoli et al., 2018).

\section{CONVERSION OF FOREST BIOMASS INTO LIQUID BIOFUELS}

The pollution caused by diesel combustion in diesel engines is one of the main contributors to global air pollution (Aghbashlo et al., 2017b; 2018b). The most crucial emissions released from diesel combustion are $\mathrm{CO}_{2}, \mathrm{NO}_{\mathrm{X}}$, sulfur oxides $\left(\mathrm{SO}_{\mathrm{X}}\right), \mathrm{CO}$, and $\mathrm{PM}$ emissions (Aghbashlo et al., 2021b). There is evidence that these emissions play a crucial role in damage to the environment and human health (Hosseinzadeh-Bandbafha et al., 2020). To solve the problem associated with diesel exhaust emissions and to mitigate the existing environmental pressure, cleaner alternatives to diesel are widely sought (Khalife et al., 2017; Aghbashlo et al., 2018a).

Biodiesel, long-chain fatty acid methyl or ethyl esters (FAME or FAEE, respectively) is produced mainly via the transesterification reaction using short-chain alcohols, i.e., methanol or ethanol, and in the presence of a base or acid catalyst (Chuah et al., 2017; Hajjari et al., 2017). Compared with diesel, biodiesel combustion leads to lower smoke, PM CO, and unburned hydrocarbon (HC) emissions (Amid et al., 2020). Also, it contributes much less to global warming than diesel because the carbon contained in biodiesel is mainly of biogenic $\mathrm{CO}_{2}$ origin (Hosseinzadeh-Bandbafha et al., 2018). The research on biodiesel production has already reached maturity, resulting in replacing diesel with various biodiesel blends in many parts of the world. It should be quoted that neat biodiesel and its blends (up to 20\%) with diesel can be used in diesel engines without requiring engine modifications (Narasimharao et al., 2007).

Despite its advantages, some physicochemical properties of biodiesel limit its widespread application, including higher viscosity of biodiesel than fossil diesel and poor cold flow properties (Aghbashlo et al., 2015; Pang, 2019). Moreover, biodiesel production from first-generation feedstock (edible vegetable oils) has led to high production costs and triggered competition between fuel and food over arable land water resources (Aghbashlo et al., 2017a). Fuels derived from waste biomass are classified as second-generation biofuels and are regarded as a solution to overcome the mentioned competition between food and fuel (Laesecke et al., 2017). High oil content tree species are suitable raw materials for biodiesel production (Patel et al., 2019).

Pyrolysis is also a promising thermochemical valorization technique for producing biofuels from forest waste at moderate temperatures (typically between 300 and $1,300^{\circ} \mathrm{C}$ ) (Aghbashlo et al., 2019; Yek et al., 2020) During this process, the feedstock's chemical structure faces fundamental changes (Foong et al., 2020; Ge et al., 2021). Generally, pyrolysis is known as the method with the ability to produce a variety of solid, liquid, and gaseous products depending on pyrolysis conditions (Aghbashlo et al., 2021a). Slow pyrolysis produces solid products such as biochar or charcoal, while fast pyrolysis results in the production of liquid products (bio-oil). It is reported that forest biomass is an ideal feedstock for pyrolysis (Chireshe et al., 2020), and different researchers have successfully conducted pyrolysis of forest biomass to produce bio-oil (Oasmaa et al., 2010; Puy et al., 2011; Stefanidis et al., 2015; 
TABLE 3 | Potential of different types of forest biomass for second-generation bioethanol production.

\begin{tabular}{|c|c|c|c|c|}
\hline Biomass species & Convertible materials (\%) & $\begin{array}{l}\text { Convertible materials yield } \\
\text { (t/ha/yr) }\end{array}$ & $\begin{array}{l}\text { Potential bioethanol yield } \\
\text { (L/ha) }\end{array}$ & References \\
\hline Manihot esculenta & 35 (Sugar) & 30 & $4,500-4,901$ & Zabed et al. (2016) \\
\hline Miscanthus spp. & 56-73.5 (Holocellulose) & $5-43$ & $4,600-12,400$ & Ho et al. (2014) \\
\hline Panicum virgatum & 35-70 (Holocellulose) & $5-25$ & $555-3,871$ & Zabed et al. (2016) \\
\hline Populus spp. & 56 (Holocellulose) & $2-10$ & $1,500-3,400$ & Ho et al. (2014) \\
\hline Saccharum spp. & $\begin{array}{l}\text { 12-17.6 (Sugar) } \\
61-73 \text { (Holocellulose) }\end{array}$ & $\begin{array}{c}\text { 70-122.9 (Sugar) } \\
\text { 19.6-34.4 (Holocellulose) }\end{array}$ & $5,345-9,950$ & Lebaka (2013) \\
\hline $\begin{array}{l}\text { Salix spp. } \\
\text { Triticum aestivum }\end{array}$ & $\begin{array}{l}69.9 \text { (Holocellulose) } \\
\text { 65.3-76 (Sugar) } \\
\text { 59-70 (Holocellulose) }\end{array}$ & $\begin{array}{c}5-11 \\
1.8-6.4 \text { (Sugar) } \\
6.5-11 \text { (Holocellulose) }\end{array}$ & $\begin{array}{c}769-4,026 \\
1,001-1700\end{array}$ & $\begin{array}{l}\text { Zamora et al. (2014) } \\
\text { Lebaka (2013) }\end{array}$ \\
\hline
\end{tabular}

Luo et al., 2017). It should be noted that the bio-oil produced by the pyrolysis process typically has a high oxygen and water content, and thus, it should be upgraded (van Schalkwyk et al., 2020).

Another conversion pathway to valorize forest biomass is gasification. González and García (2015) converted wood biomass into bio-oil through the gasification process and subsequent liquefaction (Fischer-Tropsch). Natarajan et al. (2014) reported that the installation of five Fischer-Tropsch plants could contribute to achieving Finland's various 2020 targets, i.e., using up to $58 \%$ of the available forest biomass for energy production, total emission reduction of $4 \%$, and powering the transportation sector with $100 \%$ biofuel. Sunde et al. (2011) also estimated that converting forest biomass and woody wastes into liquid biofuel by the Fischer-Tropsch process as a replacement for fossil diesel could reduce the overall environmental impacts of the transportation sector in Norway. GHG savings and reductions in greenhouse impacts by production and use of Fischer-Tropsch biofuel from forest residues are estimated to amount to roughly $20-90 \%$ on a 100-year timescale (Jäppinen et al., 2014). It should also be noted that in addition to reducing $\mathrm{CO}_{2}$ emissions, biofuel production from forest biomass could also offer economic opportunities, including creating new jobs (Natarajan et al., 2014).

Bioethanol production from forest biomass has also been investigated since the early 1990s (Mabee and Saddler, 2010). The lignocellulosic nature of forest biomass (such as PopulusL., Salix babylonica, and Saccharum officinarum) and its abundance mark it as a suitable feedstock for second-generation bioethanol production (Limayem and Ricke, 2012; Ko et al., 2020). International Energy Agency (IEA) estimates that the potential use of $10 \%$ of global forest and agricultural biomass in 2030 can provide 233 billion $\mathrm{L}$ of bioethanol, equivalent to 155 billion $\mathrm{L}$ of gasoline (Morales et al., 2021). The bioethanol production potentials of several forest biomass are shown in Table 3.

Bioethanol is well known as a promising substitute for petroleum-based gasoline (Huang et al., 2020; Amid et al., 2021), with considerably lower emissions throughout its life cycle (Mabee and Saddler, 2010). For example, Becerra-Ruiz et al. (2019) reported a decrease of 99, 93, and 67\% in CO, $\mathrm{HC}$, and NOx, respectively, when a $5500 \mathrm{~W}$ portable engine generator of alternating current burned bioethanol instead of gasoline. Compared to first-generation bioethanol such as corn and sugarcane-based bioethanol, second-generation bioethanol (i.e., bioethanol produced from lignocellulosic feedstocks) has significantly lower life cycle GHG emissions (Wang et al., 2020). Moreover, bioethanol yields of forest biomass are relatively higher than those of other types of biomass. In a study investigating bioethanol yields, Mabee and Saddler (2010) reported that bioethanol yields of forest biomass ranged between 0.12 and $0.3 \mathrm{~m}^{3} / \mathrm{t}$ (dry basis) vs. 0.11 and $0.27 \mathrm{~m}^{3} / \mathrm{t}$ (dry basis) for bioethanol production from agricultural residues.

The biochemical or thermochemical conversion are two primary methods used to process lignocellulosic feedstocks into bioethanol (Soltanian et al., 2020). The biochemical conversion starts with pretreatment to separate hemicellulose and lignin from cellulose and is followed by hydrolysis of cellulose to obtain fermentable sugars (Panahi et al., 2020a). Finally, sugars are fermented into ethanol (Anyanwu et al., 2018). Pretreatment is an instrumental stage of the process, and hence, its type and conditions play important roles in the overall technical viability of the whole process (Negro et al., 2020; Morales et al., 2021). The various pretreatment methods include chemical, physical, physicochemical, and biological (Sharma et al., 2020).

It should be noted that forest biomass, due to the presence of bark and juvenile wood, tends to have higher lignin contents (Zhu et al., 2015). As a result, forest biomass is more recalcitrant to bioconversion into sugars than other biomass types such as agricultural residues (Yamamoto et al., 2014). Although there are pretreatment processes to overcome such a high level of recalcitrance for efficient sugar/biofuel production, they are more time-consuming and costlier. One of these methods is steam explosion treatment which has been reported to increase bioethanol production of Hemp fiber by upto 70\% (Zhao et al., 2020). It has also been claimed that the application of surfactants, owing to their unique structure and functional properties, could improve the solubility, fluidity, bioavailability, and biodegradability of forest biomass, thereby increasing the production of bioethanol. Zheng et al. (2020) argued that tween, polyethylene glycol (PEG), and sulfonate-based surfactants could increase the conversion rate of lignocellulose by $10-20 \%$.

Compared to the biochemical conversion, thermochemical conversion, particularly gasification, can be applied to a broader range of forest biomass (Wang et al., 2020). During 
gasification of the lignocellulosic biomass at high pressure and in the absence of inert gases, lignocellulosic biomass is converted into syngas, which will then be converted into bioethanol through the Fischer-Tropsch process (Laesecke et al., 2017). Also, syngas can be utilized by the microorganism Clostridium ljungdahlii to generate bioethanol in the presence of catalysts (Limayem and Ricke, 2012).

\section{CONVERSION OF FOREST BIOMASS INTO GASEOUS BIOFUELS}

The gasification process of forest biomass leads to syngas production through a series of thermal cracking reactions (Burbano et al., 2011). Forest biomass, including seeds, leaves, tree trunks, and fruit shells, could be pyrolyzed in a fixed bed gasifier for a long time at high temperatures (above $1,200^{\circ} \mathrm{C}$ ) to produce hydrogen-rich syngas (Brachi et al., 2014; Ozbas et al., 2019), which has been highlighted as one of the most promising alternative sources of energy (Shih and Hsu, 2011). It is claimed that $1.3 \mathrm{Gt} / \mathrm{yr}$ of biomass can produce $100 \mathrm{Mt} / \mathrm{yr}$ of hydrogen (Duan et al., 2020).

During gasification, the reaction rate can be controlled by adjusting the gas flow. Using this strategy, the decomposition rate of forest biomass into hydrogen could reach 60\% (Solar et al., 2018). The cost of hydrogen production from forest biomass through gasification is about $1.18 \mathrm{USD} / \mathrm{kg} \mathrm{H} 2$ (Sarkar and Kumar, 2009), almost half of the other processes (Sarkar and Kumar, 2010). It should be noted that industrial gasification devices are usually connected with power generation equipment to generate electricity while providing gas; the former can be supplied to nearby households (Sasujit et al., 2017; Schulzke, 2019).

Adding appropriate catalysts to the gasification process can improve the gas content (Pang, 2019). In the catalytic gasification experiment of Eucalyptus residue with $\mathrm{NiO}$ as the catalyst, the total gas production increased by $30 \%$. Corujo et al (2010) also reported that through catalytic gasification, the biochar and ash contents were decreased, and the utilization rate of biomass was improved. It has been argued that catalytic cracking is more economical than traditional biofuel production methods such as pyrolysis and fermentation (Meerman and Larson, 2017).

In addition to producing hydrogen-rich syngas, forest biomass can also be used to produce biogas through anaerobic digestion (Tabatabaei et al., 2020a). The technology of converting forest biomass into $\mathrm{CH}_{4}$ is relatively mature and has been used for practical production for many years (González et al., 2006; Tabatabaei et al., 2020b). The production of biogas, whose main components are $\mathrm{CH}_{4}$ and $\mathrm{CO}_{2}$, is largely affected by the composition of raw materials (Dehhaghi et al., 2019). It should be noted that in addition to species, the composition of forest biomass could also be affected by variations in geographical location and growth environment.

One of the main challenges of anaerobic digestion is the nondegradability of lignin under anaerobic conditions (Dehhaghi et al., 2019). In better words, lignocellulose-rich organic materials such as forest biomass suffer from the disadvantage of low availability of cellulose and hemicellulose as biodegradable components for microorganisms and their enzymes (Lópe et al., 2013). Nevertheless, similar to other types of lignocellulosic biomass, chemical (hydrolysis with acids, alkali, or oxidants), physical (irradiation, shredding, thermal, and pressure shocks), and biological (fungi, actinobacteria, or their enzymes) pretreatments could also be employed to improve the anaerobic biodegradation of forest biomass (Chang and Holtzapple, 2000; Taherzadeh and Karimi, 2008; Hendriks and Zeeman, 2009).

\section{CONCLUSION}

It was shown that forest biomass could, directly and indirectly, be used as an energy resource. More specifically, forest biomass can be directly combusted to reduce $\mathrm{CO}_{2}$ emissions associated with conventional energy production processes. However, the energy conversion rate of forest biomass is low, and it also leads to emissions of soot and residues. Also, the lack of continuous access to biomass and the need for lots of financial investment and storage capacity are among the severe concerns in the sustainability of direct electricity generation using forest biomass.

In comparison, co-combustion of biomass and coal vs. combustion of coal alone could be regarded as a promising strategy to reduce emissions while ensuring production efficiency. It also partly solves issues related to biomass availability, the area required for storage, and economic problems related to transportation and distribution. Despite these desirable features, forest biomass suffers from poor energy density and high moisture, which could be addressed by pelleting forest biomass. Due to the improved density and moisture, direct combustion of pelleted forest biomass or its co-combustion with coal accelerates the combustion rate. Nevertheless, power plants relying on forest biomass pellets also face several problems such as high energy consumption, labor-intensive process, and higher prices than other solid biofuels. Forest biomass also can be converted into bio-oil, bioethanol, and biogas by biochemical and thermochemical methods, which are critically explained in the present work.

Given the growing awareness about the environmental consequences of burning fossil fuels, the future will undoubtedly shift toward the use of more biomass and biofuels. Although forest biomass conversion processes to bioenergy are well known, as mentioned, their long-term sustainability should be more extensively scrutinized by future studies using advanced sustainability assessment tools such as life cycle assessment, exergy, etc.

\section{AUTHOR CONTRIBUTIONS}

All authors listed have made a substantial, direct, and intellectual contribution to the work and approved it for publication.

\section{FUNDING}

The article is supported by the Program for Innovative Research Team (in Science and Technology) in University of Henan Province (No. 21IRTSTHN020) and Central Plain Scholar Funding Project of Henan Province (No. 212101510005). 


\section{REFERENCES}

Abdoli, M. A., Golzary, A., Hosseini, A., and Sadeghi, P. (2018). "Wood Pellet," in Wood Pellet As a Renewable Source Of Energy (Springer), 47-60. doi:10.1007/ 978-3-319-74482-7 3

Aghbashlo, M., Tabatabaei, M., Mohammadi, P., Pourvosoughi, N., Nikbakht, A. M., and Goli, S. A. H. (2015). Improving Exergetic and Sustainability Parameters of a DI Diesel Engine Using Polymer Waste Dissolved in Biodiesel as a Novel Diesel Additive. Energy Convers. Manag. 105, 28-337. doi:10.1016/j.enconman.2015.07.075

Aghbashlo, M., Hosseinpour, S., Tabatabaei, M., and Dadak, A. (2017a). Fuzzy Modeling and Optimization of the Synthesis of Biodiesel from Waste Cooking Oil (WCO) by a Low Power, High Frequency Piezo-Ultrasonic Reactor. Energy 132, 65-78. doi:10.1016/j.energy.2017.05.041

Aghbashlo, M., Tabatabaei, M., Mohammadi, P., Khoshnevisan, B., Rajaeifar, M. A., and Pakzad, M. (2017b). Neat Diesel Beats Waste-Oriented Biodiesel from the Exergoeconomic and Exergoenvironmental point of Views. Energ. Convers. Manage. 148, 1-15. doi:10.1016/j.enconman.2017.05.048

Aghbashlo, M., Tabatabaei, M., and Hosseinpour, S. (2018a). On the Exergoeconomic and Exergoenvironmental Evaluation and Optimization of Biodiesel Synthesis from Waste Cooking Oil (WCO) Using a Low Power, High Frequency Ultrasonic Reactor. Energ. Convers. Manage. 164, 385-398. doi:10.1016/j.enconman.2018.02.086

Aghbashlo, M., Tabatabaei, M., Khalife, E., Roodbar Shojaei, T., and Dadak, A. (2018b). Exergoeconomic Analysis of a DI Diesel Engine Fueled with Diesel/ biodiesel (B5) Emulsions Containing Aqueous Nano Cerium Oxide. Energy 149, 967-978. doi:10.1016/j.energy.2018.02.082

Aghbashlo, M., Tabatabaei, M., Nadian, M. H., Davoodnia, V., and Soltanian, S. (2019). Prognostication of Lignocellulosic Biomass Pyrolysis Behavior Using ANFIS Model Tuned by PSO Algorithm. Fuel 253, 189-198. doi:10.1016/ j.fuel.2019.04.169

Aghbashlo, M., Almasi, F., Jafari, A., Nadian, M. H., Soltanian, S., Lam, S. S., et al. (2021a). Describing Biomass Pyrolysis Kinetics Using a Generic Hybrid Intelligent Model: A Critical Stage in Sustainable Waste-Oriented Biorefineries. Renew. Energ. 170, 81-91. doi:10.1016/j.renene.2021.01.111

Aghbashlo, M., Peng, W., Tabatabaei, M., Kalogirou, S. A., Soltanian, S., Hosseinzadeh-Bandbafha, H., et al. (2021b). Machine Learning Technology in Biodiesel Research: A Review. Prog. Energ. Combustion Sci. 85, 100904. doi:10.1016/j.pecs.2021.100904

Amid, S., Aghbashlo, M., Tabatabaei, M., Hajiahmad, A., Najafi, B., Ghaziaskar, H. S., et al. (2020). Effects of Waste-Derived Ethylene Glycol Diacetate as a Novel Oxygenated Additive on Performance and Emission Characteristics of a Diesel Engine Fueled with Diesel/biodiesel Blends. Energ. Convers. Manage. 203, 112245. doi:10.1016/j.enconman.2019.112245

Amid, S., Aghbashlo, M., Tabatabaei, M., Karimi, K., Nizami, A.-S., Rehan, M., et al. (2021). Exergetic, Exergoeconomic, and Exergoenvironmental Aspects of an Industrial-Scale Molasses-Based Ethanol Production Plant. Energ. Convers. Manage. 227, 113637. doi:10.1016/j.enconman.2020.113637

Anyanwu, R., Rodriguez, C., Durrant, A., and Olabi, A.-G. (2018). "Micromacroalgae Properties and Applications," In Reference Module In Materials Science And Materials Engineering. Elsevier BV. doi:10.1016/b978-0-12803581-8.09259-6

Becerra-Ruiz, J. D., Gonzalez-Huerta, R. G., Gracida, J., Amaro-Reyes, A., and Macias-Bobadilla, G. (2019). Using green-hydrogen and Bioethanol Fuels in Internal Combustion Engines to Reduce Emissions. Int. J. Hydrogen Energ. 44, 12324-12332. doi:10.1016/j.ijhydene.2019.02.211

Böttcher, H., and Graichen, J. (2015). Impacts on the EU 2030 Climate Target of Including LULUCF in the Climate and Energy Policy Framework. Available at: http://www.oeko.de/oekodoc/2320/2015-491-en.pdf (Accessed June 25, 2020).

Brachi, P., Chirone, R., Miccio, F., Miccio, M., Picarelli, A., and Ruoppolo, G. (2014). Fluidized Bed Co-gasification of Biomass and Polymeric Wastes for a Flexible End-Use of the Syngas: Focus on Bio-Methanol. Fuel 128, 88-98. doi:10.1016/j.fuel.2014.02.070

Burbano, H. J., Pareja, J., and Amell, A. A. (2011). Laminar Burning Velocities and Flame Stability Analysis of H2/CO/air Mixtures with Dilution of N2 and CO2. Int. J. Hydrogen Energ. 36, 3232-3242. doi:10.1016/j.ijhydene.2010.11.089
Calvo, A. I., Tarelho, L. A. C., Teixeira, E. R., Alves, C., Nunes, T., Duarte, M., et al. (2013). Particulate Emissions from the Co-combustion of forest Biomass and Sewage Sludge in a Bubbling Fluidised Bed Reactor. Fuel Process. Technol. 114, 58-68. doi:10.1016/j.fuproc.2013.03.021

Campbell, N., and Mika, A. (2009). VCC Report - Evaluating Potential Uses of Vermont's Wood Biomass for Greenhouse Gas Mitigation. Available at: https:// citeseerx.ist.psu.edu/viewdoc/download?doi=10.1.1.580.8954\&rep=rep1\&type=pdf (Accessed June 25, 2021).

Chang, V. S., and Holtzapple, M. T. (2000). "Fundamental Factors Affecting Biomass Enzymatic Reactivity," in Twenty-first Symposium on Biotechnology for Fuels and Chemicals (Springer), 5-37. doi:10.1007/978-1-4612-1392-5_1

Chen, H., Xue, K., Wu, Y., Xu, G., Jin, X., and Liu, W. (2021). Thermodynamic and Economic Analyses of a Solar-Aided Biomass-Fired Combined Heat and Power System. Energy 214, 119023. doi:10.1016/j.energy.2020.119023

Chireshe, F., Collard, F.-X., and Görgens, J. F. (2020). Production of Low Oxygen Bio-Oil via Catalytic Pyrolysis of forest Residues in a Kilogram-Scale Rotary kiln Reactor. J. Clean. Prod. 260, 120987. doi:10.1016/j.jclepro.2020.120987

Chuah, L. F., Klemeš, J. J., Yusup, S., Bokhari, A., and Akbar, M. M. (2017). A Review of Cleaner Intensification Technologies in Biodiesel Production. J. Clean. Prod. 146, 181-193. doi:10.1016/j.jclepro.2016.05.017

Civitarese, V., Faugno, S., Picchio, R., Assirelli, A., Sperandio, G., Saulino, L., et al. (2018). Production of Selected Short-Rotation wood Crop Species and Quality of Obtained Biomass. Eur. J. For. Res 137, 541-552. doi:10.1007/s10342-0181122-3

Corujo, A., Yermán, L., Arizaga, B., Brusoni, M., and Castiglioni, J. (2010). Improved Yield Parameters in Catalytic Steam Gasification of Forestry Residue; Optimizing Biomass Feed Rate and Catalyst Type. Biomass Bioenergy 34, 1695-1702. doi:10.1016/j.biombioe.2010.06.010

Dai, J., Sokhansanj, S., Grace, J. R., Bi, X., Lim, C. J., and Melin, S. (2008). Overview and Some Issues Related to Co-firing Biomass and Coal. Can. J. Chem. Eng. 86, 367-386. doi:10.1002/cjce.20052

de Souza, H. J. P. L., Arantes, M. D. C., Vidaurre, G. B., Andrade, C. R., Carneiro, A. d. C. O., de Souza, D. P. L., et al. (2020). Pelletization of eucalyptus wood and Coffee Growing Wastes: Strategies for Biomass Valorization and Sustainable Bioenergy Production. Renew. Energ. 149, 128-140. doi:10.1016/ j.renene.2019.12.015

Dehhaghi, M., Tabatabaei, M., Aghbashlo, M., Kazemi Shariat Panahi, H., and Nizami, A.-S. (2019). A State-Of-The-Art Review on the Application of Nanomaterials for Enhancing Biogas Production. J. Environ. Manage. 251, 109597. doi:10.1016/j.jenvman.2019.109597

Del Giudice, A., Acampora, A., Santangelo, E., Pari, L., Bergonzoli, S., Guerriero, E., et al. (2019). Wood Chip Drying through the Using of a mobile Rotary Dryer. Energies 12, 1590. doi:10.3390/en12091590

Demirba, A. (2005). Influence of Gas and Detrimental Metal Emissions from Biomass Firing and Co-firing on Environmental Impact. Energ. Sourc. 27, 1419-1428. doi:10.1080/009083190523271

Dincer, I., and Bicer, Y. (2020). "Fundamentals of Energy Systems," in Fundamentals of Energy Systems, Integrated Energy Systems for Multigeneration (Amsterdam, Netherlands: Elsevier), 33-83.

Dote, Y., Ogi, T., and Yokoyama, S. (2001). "Estimate of the Net CO2, Reduction by Replacing Coal and Oil with Biomass in Japan," in Progress in Thermochemical Biomass Conversion (Hoboken, New Jersey: John Wiley \& Sons), 956-963.

Duan, Y., Pandey, A., Zhang, Z., Awasthi, M. K., Bhatia, S. K., and Taherzadeh, M. J. (2020). Organic Solid Waste Biorefinery: Sustainable Strategy for Emerging Circular Bioeconomy in China. Ind. Crops Prod. 153, 112568. doi:10.1016/ j.indcrop. 2020.112568

Ehrig, R., and Behrendt, F. (2013). Co-firing of Imported wood Pellets - an Option to Efficiently Save CO2 Emissions in Europe? Energy Policy 59, 283-300. doi:10.1016/j.enpol.2013.03.060

Foong, S. Y., Liew, R. K., Yang, Y., Cheng, Y. W., Yek, P. N. Y., Wan Mahari, W. A., et al. (2020). Valorization of Biomass Waste to Engineered Activated Biochar by Microwave Pyrolysis: Progress, Challenges, and Future Directions. Chem. Eng. J. 389, 124401. doi:10.1016/j.cej.2020.124401

Frodeson, S., Berghel, J., and Renström, R. (2013). The Potential of Using Two-step Drying Techniques for Improving Energy Efficiency and Increasing Drying Capacity in Fuel Pellet Industries. Drying Technol. 31, 1863-1870. doi:10.1080/ 07373937.2013 .833520 
Froese, R. E., Shonnard, D. R., Miller, C. A., Koers, K. P., and Johnson, D. M. (2010). An Evaluation of Greenhouse Gas Mitigation Options for Coal-Fired Power Plants in the US Great Lakes States. Biomass Bioenergy 34, 251-262. doi:10.1016/j.biombioe.2009.10.013

Furubayashi, T., and Nakata, T. (2018). Cost and CO2 Reduction of Biomass CoFiring Using Waste Wood Biomass in Tohoku Region, Japan. J. Clean. Prod. 174, 1044-1053.

Ge, S., Yek, P. N. Y., Cheng, Y. W., Xia, C., Mahari, W. A. W., Liew, R. K., et al. (2021). Progress in Microwave Pyrolysis Conversion of Agricultural Waste to Value-Added Biofuels: A Batch to Continuous Approach. Renew. Sustain. Energ. Rev. 135, 110148. doi:10.1016/j.rser.2020.110148

González, J. F., Gañán, J., Ramiro, A., González-García, C. M., Encinar, J. M., Sabio, E., et al. (2006). Almond Residues Gasification Plant for Generation of Electric Power. Preliminary Study. Fuel Process. Technol. 87, 149-155. doi:10.1016/ j.fuproc.2005.08.010

González, J., and García, A. (2015). Availability of forest Biomass in Chile for Second Generation Biodiesel Production. International Congress of Energy and Environment Engineering and Management.

Gustavsson, L., Haus, S., Ortiz, C. A., Sathre, R., and Truong, N. L. (2015). Climate Effects of Bioenergy from forest Residues in Comparison to Fossil Energy. Appl. Energ. 138, 36-50. doi:10.1016/j.apenergy.2014.10.013

Hajjari, M., Tabatabaei, M., Aghbashlo, M., and Ghanavati, H. (2017). A Review on the Prospects of Sustainable Biodiesel Production: A Global Scenario with an Emphasis on Waste-Oil Biodiesel Utilization. Renew. Sustain. Energ. Rev. 72, 445-464. doi:10.1016/j.rser.2017.01.034

Hendriks, A. T. W. M., and Zeeman, G. (2009). Pretreatments to Enhance the Digestibility of Lignocellulosic Biomass. Bioresour. Technol. 100, 10-18. doi:10.1016/j.biortech.2008.05.027

Ho, D. P., Ngo, H. H., and Guo, W. (2014). A Mini Review on Renewable Sources for Biofuel. Bioresour. Technol. 169, 742-749. doi:10.1016/ j.biortech.2014.07.022

Hoffmann, B. S., Szklo, A., and Schaeffer, R. (2012). An Evaluation of the TechnoEconomic Potential of Co-firing Coal with Woody Biomass in thermal Power Plants in the South of Brazil. Biomass Bioenergy 45, 295-302. doi:10.1016/ j.biombioe.2012.06.016

Hong-ru, M., and Yi-hu, S. (2007). Study on Direct-Combustion Technology of Biomass [J]. J. Agric. Mech. Res. 8.

Hosseinzadeh-Bandbafha, H., Tabatabaei, M., Aghbashlo, M., Khanali, M., and Demirbas, A. (2018). A Comprehensive Review on the Environmental Impacts of Diesel/biodiesel Additives. Energ. Convers. Manage. 174, 579-614. doi:10.1016/j.enconman.2018.08.050

Hosseinzadeh-Bandbafha, H., Tabatabaei, M., Aghbashlo, M., Khanali, M., Khalife, E., Roodbar Shojaei, T., et al. (2020). Consolidating Emission Indices of a Diesel Engine Powered by Carbon Nanoparticle-Doped Diesel/biodiesel Emulsion Fuels Using Life Cycle Assessment Framework. Fuel 267, 117296. doi:10.1016/ j.fuel.2020.117296

Huang, C., Fang, G., Yu, L., Zhou, Y., Meng, X., Deng, Y., et al. (2020). Maximizing Enzymatic Hydrolysis Efficiency of Bamboo with a Mild Ethanol-Assistant Alkaline Peroxide Pretreatment. Bioresour. Technol. 299, 122568. doi:10.1016/ j.biortech.2019.122568

Ince, P. J., Kramp, A. D., Skog, K. E., Yoo, D.-i., and Sample, V. A. (2011). Modeling Future U.S. forest Sector Market and Trade Impacts of Expansion in wood Energy Consumption. Jfe 17, 142-156. doi:10.1016/j.jfe.2011.02.007

Jäppinen, E., Korpinen, O.-J., and Ranta, T. (2014). GHG Emissions of forest-biomass Supply Chains to Commercial-Scale Liquid-Biofuel Production Plants in Finland. Gcb Bioenergy 6, 290-299. doi:10.1111/ gcbb. 12048

Jun-jun, L., and Da-rui, W. (2012). Considerations about Developing Future Energy. Oil Forum 4.

Kabir, M. R., and Kumar, A. (2012). Comparison of the Energy and Environmental Performances of Nine Biomass/coal Co-firing Pathways. Bioresour. Technol. 124, 394-405. doi:10.1016/j.biortech.2012.07.106

Kacprzak, A., Kobyłecki, R., Włodarczyk, R., and Bis, Z. (2016). Efficiency of Nonoptimized Direct Carbon Fuel Cell with Molten Alkaline Electrolyte Fueled by Carbonized Biomass. J. Power Sourc. 321, 233-240. doi:10.1016/ j.jpowsour.2016.04.132

Kang, K., Zhu, M., Sun, G., Qiu, L., Guo, X., Meda, V., et al. (2018). Codensification of Eucommia Ulmoides Oliver Stem with Pyrolysis Oil and Char for Solid
Biofuel: An Optimization and Characterization Study. Appl. Energ. 223, 347-357. doi:10.1016/j.apenergy.2018.04.069

Karaj, S., Rehl, T., Leis, H., and Müller, J. (2010). Analysis of Biomass Residues Potential for Electrical Energy Generation in Albania. Renew. Sustain. Energ. Rev. 14, 493-499. doi:10.1016/j.rser.2009.07.026

Kazagic, A., Music, M., Smajevic, I., Ademovic, A., and Redzic, E. (2016). Possibilities and Sustainability of "biomass for Power" Solutions in the Case of a Coal-Based Power Utility. Clean. Techn Environ. Pol. 18, 1675-1683. doi:10.1007/s10098-016-1193-0

Khalife, E., Tabatabaei, M., Demirbas, A., and Aghbashlo, M. (2017). Impacts of Additives on Performance and Emission Characteristics of Diesel Engines during Steady State Operation. Prog. Energ. Combustion Sci. 59, 32-78. doi:10.1016/j.pecs.2016.10.001

Ko, J. K., Lee, J. H., Jung, J. H., and Lee, S.-M. (2020). Recent Advances and Future Directions in Plant and Yeast Engineering to Improve Lignocellulosic Biofuel Production. Renew. Sustain. Energ. Rev. 134, 110390. doi:10.1016/ j.rser.2020.110390

Laesecke, J., Ellis, N., and Kirchen, P. (2017). Production, Analysis and Combustion Characterization of Biomass Fast Pyrolysis Oil - Biodiesel Blends for Use in Diesel Engines. Fuel 199, 346-357. doi:10.1016/ j.fuel.2017.01.093

Lam, M. K., Loy, A. C. M., Yusup, S., and Lee, K. T. (2019). "Biohydrogen Production from Algae," in Biohydrogen. Elsevier, 219-245. doi:10.1016/b9780-444-64203-5.00009-5

Lebaka, V. R. (2013). "Potential Bioresources as Future Sources of Biofuels Production: An Overview," in Biofuel Technologies: Recent Developments (Berlin, Heidelberg: Springer).

Liang, F., Wang, R., Jiang, C., Yang, X., Zhang, T., Hu, W., et al. (2017). Investigating Co-combustion Characteristics of Bamboo and wood. Bioresour. Technol. 243, 556-565. doi:10.1016/j.biortech.2017.07.003

Liao, C., Wu, C., and Huang, H. (2004). Study on the Distribution and Quantity of Biomass Residues Resource in China. Biomass Bioenergy 27, 111-117. doi:10.1016/j.biombioe.2003.10.009

Limayem, A., and Ricke, S. C. (2012). Lignocellulosic Biomass for Bioethanol Production: Current Perspectives, Potential Issues and Future Prospects. Prog. Energ. Combustion Sci. 38, 449-467. doi:10.1016/j.pecs.2012.03.002

Lópe, M., Suárez-Estrella, F., Vargas-García, M. C., López-González, J. A., Verstichel, S., Debeer, L., et al. (2013). Biodelignification of Agricultural and forest Wastes: Effect on Anaerobic Digestion. Biomass bioenergy 58, 343-349. doi:10.1016/j.biombioe.2013.10.021

Luo, G., Chandler, D. S., Anjos, L. C. A., Eng, R. J., Jia, P., and Resende, F. L. P. (2017). Pyrolysis of Whole wood Chips and Rods in a Novel Ablative Reactor. Fuel 194, 229-238. doi:10.1016/j.fuel.2017.01.010

Mabee, W. E., and Saddler, J. N. (2010). Bioethanol from Lignocellulosics: Status and Perspectives in Canada. Bioresour. Technol. 101, 4806-4813. doi:10.1016/ j.biortech.2009.10.098

Mallaki, M., and Fatehi, R. (2014). Design of a Biomass Power Plant for Burning Date Palm Waste to Cogenerate Electricity and Distilled Water. Renew. Energy 63, 286-291.

McIlveen-Wright, D. R., Huang, Y., Rezvani, S., Mondol, J. D., Redpath, D., Anderson, M., et al. (2011). A Techno-Economic Assessment of the Reduction of Carbon Dioxide Emissions through the Use of Biomass Co-combustion 2 . Fuel 90, 11-18. doi:10.1016/j.fuel.2010.08.022

Meerman, J. C., and Larson, E. D. (2017). Negative-carbon Drop-In Transport Fuels Produced via Catalytic Hydropyrolysis of Woody Biomass with CO2capture and Storage. Sustain. Energ. Fuels 1, 866-881. doi:10.1039/ c7se00013h

Moiseyev, A., Solberg, B., and Kallio, A. M. I. (2014). The Impact of Subsidies and Carbon Pricing on the wood Biomass Use for Energy in the EU. Energy 76, 161-167. doi:10.1016/j.energy.2014.05.051

Molina-Moreno, V., Leyva-Díaz, J., and Sánchez-Molina, J. (2016). Pellet as a Technological Nutrient within the Circular Economy Model: Comparative Analysis of Combustion Efficiency and $\mathrm{CO}$ and NOx Emissions for Pellets from Olive and almond Trees. Energies 9, 777. doi:10.3390/en9100777

Morales, M., Arvesen, A., and Cherubini, F. (2021). Integrated Process Simulation for Bioethanol Production: Effects of Varying Lignocellulosic Feedstocks on Technical Performance. Bioresour. Technol. 328, 124833. doi:10.1016/ j.biortech.2021.124833 
Morrison, B., Daystar, J., and Golden, J. S. (2018). Substituting wood Pellets for Coal in Large-Scale Power Stations: a Dynamic Life Cycle Assessment Examination. Ijgei 41, 272-288. doi:10.1504/ijgei.2018.10018219

Nakano, S., Murano, A., and Washizu, A. (2015). Economic and Environmental Effects of Utilizing Unused Woody Biomass. J. Japan Inst. Energy 94, 522-531.

Narasimharao, K., Lee, A., and Wilson, K. (2007). Catalysts in Production of Biodiesel: a Review. $j$ biobased mat bioenergy 1, 19-30. doi:10.1166/ jbmb.2007.1976

Natarajan, K., Leduc, S., Pelkonen, P., Tomppo, E., and Dotzauer, E. (2014). Optimal Locations for Second Generation Fischer Tropsch Biodiesel Production in Finland. Renew. Energ. 62, 319-330. doi:10.1016/ j.renene.2013.07.013

Negro, M. J., Álvarez, C., Doménech, P., Iglesias, R., and Ballesteros, I. (2020). Sugars Production from Municipal Forestry and Greening Wastes Pretreated by an Integrated Steam Explosion-Based Process. Energies 13, 4432. doi:10.3390/ en13174432

Nunes, L. J. R., Matias, J. C. O., and Catalão, J. P. S. (2014). A Review on Torrefied Biomass Pellets as a Sustainable Alternative to Coal in Power Generation. Renew. Sustain. Energy Rev. 40, 153-160.

Nunes, L. J. R., Godina, R., Matias, J. C. O., and Catalão, J. P. S. (2018). Economic and Environmental Benefits of Using Textile Waste for the Production of thermal Energy. J. Clean. Prod. 171, 1353-1360. doi:10.1016/ j.jclepro.2017.10.154

Oasmaa, A., Solantausta, Y., Arpiainen, V., Kuoppala, E., and Sipilä, K. (2010). Fast Pyrolysis Bio-Oils from wood and Agricultural Residues. Energy Fuels 24, 1380-1388. doi:10.1021/ef901107f

Ozbas, E. E., Aksu, D., Ongen, A., Aydin, M. A., and Ozcan, H. K. (2019). Hydrogen Production via Biomass Gasification, and Modeling by Supervised Machine Learning Algorithms. Int. J. Hydrogen Energ. 44, 17260-17268. doi:10.1016/ j.ijhydene.2019.02.108

Palšauskas, M. ys., and Petkevičius, S. (2013). A New Approach to Renewable Energy: New Mixed Biomass Pellets. J. Food Agric. Environ. 11, 798-802.

Panahi, H. K. S., Dehhaghi, M., Aghbashlo, M., Karimi, K., and Tabatabaei, M. (2020a). Conversion of Residues from Agro-Food Industry into Bioethanol in Iran: An Under-valued Biofuel Additive to Phase Out MTBE in Gasoline. Renew. Energ. 145, 699-710. doi:10.1016/ j.renene.2019.06.081

Panahi, H. K. S., Dehhaghi, M., Ok, Y. S., Nizami, A.-S., Khoshnevisan, B., Mussatto, S. I., et al. (2020b). A Comprehensive Review of Engineered Biochar: Production, Characteristics, and Environmental Applications. J. Clean. Prod. 270, 122462. doi:10.1016/j.jclepro.2020.122462

Pang, S. (2019). Advances in Thermochemical Conversion of Woody Biomass to Energy, Fuels and Chemicals. Biotechnol. Adv. 37, 589-597. doi:10.1016/ j.biotechadv.2018.11.004

Patel, M., Oyedun, A. O., Kumar, A., and Gupta, R. (2019). What is the Production Cost of Renewable Diesel from Woody Biomass and Agricultural Residue Based on Experimentation? A Comparative Assessment. Fuel Process. Technol. 191, 79-92.

Perea-Moreno, A.-J., Perea-Moreno, M.-Á., Hernandez-Escobedo, Q., and Manzano-Agugliaro, F. (2017). Towards forest Sustainability in Mediterranean Countries Using Biomass as Fuel for Heating. J. Clean. Prod. 156, 624-634. doi:10.1016/j.jclepro.2017.04.091

Perez-Garcia, J., Lippke, B., Comnick, J., and Manriquez, C. (2005). An Assessment of Carbon Pools, Storage, and wood Products Market Substitution Using LifeCycle Analysis Results. Wood Fiber Sci. 37, 140-148.

Pour, N., Webley, P. A., and Cook, P. J. (2018). Opportunities for Application of BECCS in the Australian Power Sector. Appl. Energ. 224, 615-635. doi:10.1016/ j.apenergy.2018.04.117

Pradhan, P., Arora, A., and Mahajani, S. M. (2018). Pilot Scale Evaluation of Fuel Pellets Production from Garden Waste Biomass. Energ. Sustain. Dev. 43, 1-14. doi:10.1016/j.esd.2017.11.005

Prokkola, H. E., Kuokkanen, M., Kuokkanen, T., and Lassi, U. (2014). Chemical Study of wood Chip Drying: Biodegradation of Organic Pollutants in Condensate Waters from the Drying Process. BioResources 9, 3761-3778. doi:10.15376/biores.9.3.3761-3778

Purohit, P., and Chaturvedi, V. (2018). Biomass Pellets for Power Generation in India: a Techno-Economic Evaluation. Environ. Sci. Pollut. Res. 25, 29614-29632. doi:10.1007/s11356-018-2960-8
Puy, N., Murillo, R., Navarro, M. V., López, J. M., Rieradevall, J., Fowler, G., et al. (2011). Valorisation of Forestry Waste by Pyrolysis in an Auger Reactor. Waste Manage. 31, 1339-1349. doi:10.1016/j.wasman.2011.01.020

Raunikar, R., Buongiorno, J., Turner, J. A., and Zhu, S. (2010). Global Outlook for wood and Forests with the Bioenergy Demand Implied by Scenarios of the Intergovernmental Panel on Climate Change. For. Pol. Econ. 12, 48-56. doi:10.1016/j.forpol.2009.09.013

Royo, J., Sebastián, F., García-Galindo, D., Gómez, M., and Díaz, M. (2012). Largescale Analysis of GHG (Greenhouse Gas) Reduction by Means of Biomass Cofiring at Country-Scale: Application to the Spanish Case. Energy 48, 255-267. doi:10.1016/j.energy.2012.06.046

Sandro, N., Agis, P., Gojmir, R., Vlasta, Z., and Müslüm, A. (2019). Using Pellet Fuels for Residential Heating: A Field Study on its Efficiency and the Users' Satisfaction. Energy and Buildings 184, 193-204. doi:10.1016/ j.enbuild.2018.12.007

Sarkar, S., and Kumar, A. (2010). Large-scale Biohydrogen Production from BioOil. Bioresour. Technol. 101, 7350-7361. doi:10.1016/j.biortech.2010.04.038

Sarkar, S., and Kumar, A. (2009). Techno-Economic Assessment of Biohydrogen Production from Forest Biomass in Western Canada. Trans. ASABE 52, 519-530.

Sasujit, K., Dussadee, N., Homdoung, N., Ramaraj, R., and Kiatsiriroat, T. (2017). Waste-to-Energy: Producer Gas Production from Fuel Briquette of Energy Crop in Thailand. Int. Energ. J. 17, 37-46.

Scarlat, N., Blujdea, V., and Dallemand, J.-F. (2011). Assessment of the Availability of Agricultural and forest Residues for Bioenergy Production in Romania. Biomass Bioenergy 35, 1995-2005. doi:10.1016/j.biombioe.2011.01.057

Schulzke, T. (2019). Biomass Gasification: Conversion of forest Residues into Heat, Electricity and Base Chemicals. Chem. Pap. 78, 1833-1852. doi:10.1007/s11696019-00801-1

Searle, S. Y., and Malins, C. J. (2016). Waste and Residue Availability for Advanced Biofuel Production in EU Member States. Biomass Bioenergy 89, 2-10. doi:10.1016/j.biombioe.2016.01.008

Sharma, B., Larroche, C., and Dussap, C.-G. (2020). Comprehensive Assessment of 2G Bioethanol Production. Bioresour. Technol. 313, 123630. doi:10.1016/ j.biortech.2020.123630

Shih, H.-Y., and Hsu, J.-R. (2011). A Computational Study of Combustion and Extinction of Opposed-Jet Syngas Diffusion Flames. Int. J. Hydrogen Energ. 36, 15868-15879. doi:10.1016/j.ijhydene.2011.09.037

Sikkema, R., Steiner, M., Junginger, M., Hiegl, W., Hansen, M. T., and Faaij, A. (2011). The European wood Pellet Markets: Current Status and Prospects for 2020. Biofuels, Bioprod. Bioref. 5, 250-278. doi:10.1002/bbb.277

Solar, J., Caballero, B., De Marco, I., López-Urionabarrenechea, A., and Gastelu, N. (2018). Optimization of Charcoal Production Process from Woody Biomass Waste: Effect of Ni-Containing Catalysts on Pyrolysis Vapors. Catalysts 8, 191. doi:10.3390/catal8050191

Soltanian, S., Aghbashlo, M., Almasi, F., Hosseinzadeh-Bandbafha, H., Nizami, A.S., Ok, Y. S., et al. (2020). A Critical Review of the Effects of Pretreatment Methods on the Exergetic Aspects of Lignocellulosic Biofuels. Energ. Convers. Manage. 212, 112792. doi:10.1016/j.enconman.2020.112792

Stefanidis, S. D., Heracleous, E., Patiaka, D. T., Kalogiannis, K. G., Michailof, C. M., and Lappas, A. A. (2015). Optimization of Bio-oil Yields by Demineralization of Low Quality Biomass. Biomass Bioenergy 83, 105-115.

Sunde, K., Brekke, A., and Solberg, B. (2011). Environmental Impacts and Costs of Woody Biomass-To-Liquid (BTL) Production and Use - A Review. For. Pol. Econ. 13, 591-602. doi:10.1016/j.forpol.2011.05.008

Tabatabaei, M., Aghbashlo, M., Valijanian, E., Kazemi Shariat Panahi, H., Nizami, A.-S., Ghanavati, H., et al. (2020a). A Comprehensive Review on Recent Biological Innovations to Improve Biogas Production, Part 1: Upstream Strategies. Renew. Energ. 146, 1204-1220. doi:10.1016/ j.renene.2019.07.037

Tabatabaei, M., Aghbashlo, M., Valijanian, E., Kazemi Shariat Panahi, H., Nizami, A.-S., Ghanavati, H., et al. (2020b). A Comprehensive Review on Recent Biological Innovations to Improve Biogas Production, Part 2: Mainstream and Downstream Strategies. Renew. Energ. 146, 1392-1407. doi:10.1016/ j.renene.2019.07.047

Taherzadeh, M., and Karimi, K. (2008). Pretreatment of Lignocellulosic Wastes to Improve Ethanol and Biogas Production: a Review. Ijms 9, 1621-1651. doi:10.3390/ijms 9091621 
Tamura, M., Watanabe, S., Kotake, N., and Hasegawa, M. (2014). Grinding and Combustion Characteristics of Woody Biomass for Co-firing with Coal in Pulverised Coal Boilers. Fuel 134, 544-553. doi:10.1016/ j.fuel.2014.05.083

Tan, Z., Chen, K., and Liu, P. (2015). Possibilities and Challenges of China's Forestry Biomass Resource Utilization. Renew. Sustain. Energ. Rev. 41, 368-378. doi:10.1016/j.rser.2014.08.059

Tsalidis, G.-A., Joshi, Y., Korevaar, G., and de Jong, W. (2014). Life Cycle Assessment of Direct Co-firing of Torrefied And/or Pelletised Woody Biomass with Coal in The Netherlands. J. Clean. Prod. 81, 168-177. doi:10.1016/j.jclepro.2014.06.049

Urban, L., Masa, V., Pavlas, M., and Stehlik, P. (2010). Novel Type of Technology for Biomass Utilization. Forestry 2020, 2030.

Valdés, C. F., Marrugo, G., Chejne, F., Cogollo, K., and Vallejos, D. (2018). Pelletization of Agroindustrial Biomasses from the Tropics as an Energy Resource: Implications of Pellet Quality. Energy Fuels 32, 11489-11501. doi:10.1021/acs.energyfuels.8b01673

Vandenbroek, R., Faaij, A., and van Wijk, A. (1996). Biomass Combustion for Power Generation. Biomass Bioenergy 11, 271-281. doi:10.1016/0961-9534(96) 00033-5

van Schalkwyk, D. L., Mandegari, M., Farzad, S., and Görgens, J. F. (2020). Technoeconomic and Environmental Analysis of Bio-Oil Production from forest Residues via Non-catalytic and Catalytic Pyrolysis Processes. Energ. Convers. Manage. 213, 112815. doi:10.1016/j.enconman.2020.112815

Vassilev, S. V., Baxter, D., Andersen, L. K., and Vassileva, C. G. (2010). An Overview of the Chemical Composition of Biomass. Fuel 89, 913-933. doi:10.1016/j.fuel.2009.10.022

Wang, H., Zhang, S., Bi, X., and Clift, R. (2020). Greenhouse Gas Emission Reduction Potential and Cost of Bioenergy in British Columbia, Canada. Energy Policy 138, 111285. doi:10.1016/j.enpol.2020.111285

Welfle, A., Gilbert, P., and Thornley, P. (2014). Securing a Bioenergy Future without Imports. Energy Policy 68, 1-14. doi:10.1016/ j.enpol.2013.11.079

Yamamoto, M., Niskanen, T., Iakovlev, M., Ojamo, H., and van Heiningen, A. (2014). The Effect of Bark on Sulfur Dioxide-Ethanol-Water Fractionation and Enzymatic Hydrolysis of forest Biomass. Bioresour. Technol. 167, 390-397. doi:10.1016/j.biortech.2014.06.019

Yek, P. N. Y., Peng, W., Wong, C. C., Liew, R. K., Ho, Y. L., Wan Mahari, W. A., et al. (2020). Engineered Biochar via Microwave CO2 and Steam Pyrolysis to Treat Carcinogenic Congo Red Dye. J. Hazard. Mater. 395, 122636. doi:10.1016/j.jhazmat.2020.122636
Yin, C., Rosendahl, L. A., and Kær, S. K. (2008). Grate-firing of Biomass for Heat and Power Production. Prog. Energ. Combustion Sci. 34, 725-754. doi:10.1016/ j.pecs.2008.05.002

Yuan, R., Yu, S., and Shen, Y. (2019). Pyrolysis and Combustion Kinetics of Lignocellulosic Biomass Pellets with Calcium-Rich Wastes from Agro-Forestry Residues. Waste Manage. 87, 86-96. doi:10.1016/j.wasman.2019.02.009

Zabed, H., Sahu, J. N., Boyce, A. N., and Faruq, G. (2016). Fuel Ethanol Production from Lignocellulosic Biomass: an Overview on Feedstocks and Technological Approaches. Renew. Sustain. Energ. Rev. 66, 751-774. doi:10.1016/ j.rser.2016.08.038

Zamora, D. S., Apostol, K. G., and Wyatt, G. J. (2014). Biomass Production and Potential Ethanol Yields of Shrub Willow Hybrids and Native Willow Accessions after a Single 3-year Harvest Cycle on Marginal Lands in central Minnesota, USA. Agroforest Syst. 88, 593-606. doi:10.1007/s10457-014-9693-6

Zhao, J., Xu, Y., Wang, W., Griffin, J., Roozeboom, K., and Wang, D. (2020). Bioconversion of Industrial Hemp Biomass for Bioethanol Production: A Review. Fuel 281, 118725. doi:10.1016/j.fuel.2020.118725

Zheng, T., Jiang, J., and Yao, J. (2020). Surfactant-promoted Hydrolysis of Lignocellulose for Ethanol Production. Fuel Process. Technol., 106660. doi:10.1016/j.fuproc.2020.106660

Zhu, J. Y., Chandra, M. S., Gu, F., Gleisner, R., Reiner, R., Sessions, J., et al. (2015). Using Sulfite Chemistry for Robust Bioconversion of Douglas-fir forest Residue to Bioethanol at High Titer and Lignosulfonate: a Pilot-Scale Evaluation. Bioresour. Technol. 179, 390-397. doi:10.1016/ j.biortech.2014.12.052

Zomer, R. J., Trabucco, A., Bossio, D. A., and Verchot, L. V. (2008). Climate Change Mitigation: A Spatial Analysis of Global Land Suitability for Clean Development Mechanism Afforestation and Reforestation. Agric. Ecosyst. Environ. 126, 67-80. doi:10.1016/j.agee.2008.01.014

Conflict of Interest: The authors declare that the research was conducted in the absence of any commercial or financial relationships that could be construed as a potential conflict of interest.

Copyright $(2021$ Yu, Wang, Van Le, Yang, Hosseinzadeh-Bandbafha, Yang, Sonne, Tabatabaei, Lam and Peng. This is an open-access article distributed under the terms of the Creative Commons Attribution License (CC BY). The use, distribution or reproduction in other forums is permitted, provided the original author $(s)$ and the copyright owner(s) are credited and that the original publication in this journal is cited, in accordance with accepted academic practice. No use, distribution or reproduction is permitted which does not comply with these terms. 